\title{
Traditional knowledge system in palung salt-making in Bali Island
}

\author{
Yety Rochwulaningsih', Singgih Tri Sulistiyono ${ }^{1}$, Mahendra Pudji Utama ${ }^{2}$, Noor Naelil Masruroh², Siti Rukayah", \\ Makhfud Efendy ${ }^{4}$ and Misri Gozan ${ }^{5^{*}}$ (D)
}

\begin{abstract}
This study presents the case of an original and traditional knowledge system of palung, which is used in saltmaking in the coastal communities of Bali. The study emphasizes the practicalities of the system and its epistemology using anthropological and sociological methods. It is known that the traditional knowledge system of palung salt production has been preserved through the generations as a form of local wisdom. This traditional knowledge system emphasizes the use of local natural resources in accordance with the coastal ecosystems of Bali, where the cultivation of extracted soil (tanah sari), sand, bamboo, and coconut trees is carried out manually. This study has evidenced that the palung process successfully produces salt of excellent taste and quality. Based on laboratory tests conducted on palung salt samples, the results show that it does not contain any heavy metals and that it has good nutritional content. Because of its use of available natural resources, this traditional knowledge system is sustainable and environmentally friendly.
\end{abstract}

Keywords: Traditional Knowledge, Salt-making , Palung, Coastal Community , Preservation, Local Technology

\section{Introduction}

In Indonesia, salt is generally produced by coastal communities. The common process of salt production is using traditional technology. However, these communities are typically weak and vulnerable in a socioeconomic sense. Therefore, identifying, analyzing, and developing the potential of coastal resources to improve the welfare of coastal communities is necessary [1]. In 2011, the Indonesian government implemented the Salt Empowerment Business Program and introduced various institutional and physical technologies [2-4]. In addition, regulations to protect and empower salt farmers and fishermen in coastal communities were implemented through Law No. 7 of 2016. With these programs and regulations, the traditional aspects of salt production are protected, thus ensuring that high-quality salt is produced. However, it is not competitive in relation to current consumption and industrial needs. The process of salt production in Bali, where palung technology is used, differs significantly in comparison with other areas of Indonesia.

\footnotetext{
* Correspondence: mrgozan@gmail.com

${ }^{5}$ Chemical Engineering Department, Faculty of Engineering, Universitas

Indonesia, Kampus UI, Depok 16424, Indonesia

Full list of author information is available at the end of the article
}

Balinese palung salt is a product that is based on the local ecosystem and the traditional knowledge of its coastal communities [5]. This technological process of salt production is unique and specific to Bali. It uses renewable, natural, and local resources, including soil, sand, bamboo, and coconut trees, in a seawater evaporation process. This means that the salt is hygienic, of high quality, and tastes good. The results of laboratory tests showed that palung salt contains no arsenic (As), copper $(\mathrm{Cu})$, or mercury $(\mathrm{Hg})$, meaning that it is devoid of harmful metals. Palung salt has good nutritional value, with moisture $(1.6 \mathrm{~g})$, protein $(0.1 \mathrm{~g})$, minerals $(98$ g), energy ( $2 \mathrm{kcal})$, and potassium (196 $\mathrm{mg})$. Thus, salt is a desirable product that can penetrate numerous markets, including Japan, Korea, France, and the USA [5]. As previously stated, the salt-making uses traditional knowledge systems. With palung salt, the knowledge system is amassed from the collective experiences of the coastal communities of Bali [6]. There is a wealth of traditional knowledge about the ecology of the area and its natural resources, and this knowledge can be used as an adaptation strategy to support efforts to improve the welfare of the area [7].

(c) The Author(s). 2019 Open Access This article is distributed under the terms of the Creative Commons Attribution 4.0 International License (http://creativecommons.org/licenses/by/4.0/), which permits unrestricted use, distribution, and reproduction in any medium, provided you give appropriate credit to the original author(s) and the source, provide a link to the Creative Commons license, and indicate if changes were made. The Creative Commons Public Domain Dedication waiver (http://creativecommons.org/publicdomain/zero/1.0/) applies to the data made available in this article, unless otherwise stated. 
The traditional knowledge system of palung saltmaking has cemented itself in the culture of Balinese coastal communities. The knowledge system is original, owned, and developed by local communities. It is developed in the form of skills, techniques, and cultural practices that allow communities to manage their natural resources [8]. This knowledge is an economic asset, as it determines the livelihoods of the local people and belongs to the community [9].

While the knowledge system of palung salt-making is traditional, it is not stagnant. It is adaptable to changing environments as a result of ecological and economic changes [5]. For example, the eruption of Mount Agung in 2017 damaged the palung industry in Buleleng and Karangasem. Likewise, the growth of the tourist industry in Bali in recent years has encouraged the commercialization of land in coastal regions. This has led to coastal land being repurposed and used as sites for resorts and hotels rather than for salt-making. In this context, many salt farmers have moved to work in tourism, thus threatening the preservation of palung methods. Thus, the current situation poses a serious threat to the existence and sustainability of palung salt. At the same time, it cannot support local communities, who need diverse economic activities in order to survive. The local food system should become along with the institutions and organizations that regulate it [10]. This phenomenon is somewhat different from other regions of Indonesia. According to Blaikie, traditional knowledge systems are vulnerable. This vulnerability is due to rapid population growth, migration, and natural disasters. These adverse changes lead to cultural divisions, land degradation, commercialization, and economic downturns [11].

This paper discusses how the traditional knowledge system of palung salt-making is preserved in Bali, the threats it faces, and the ways in which it has had to adapt. This study used anthropological and sociological methods of data collection via in-depth interviews, focus-group discussions, and after-fact observations [12] made by observing photographs related to the salt-making process in Buleleng. The in-depth interviews and focus-group discussions were conducted with salt farmers, traditional leaders, and actors in the salt and tourism sectors. The sample was selected using the snowball sampling technique [13].

\section{Local wisdom in palung technology}

This section analyzes how palung technology as a form of cultural heritage has existed for centuries as a unique element of local wisdom. The existence of this form of traditional technology dates to the pre-colonial period. Thus, the modes of palung salt-production are traditional and pre-capitalistic [5]. These characteristics remain to this day. As a traditional technological system, palung salt is closely connected with the Balinese people.
Over the centuries, it has brought numerous economic and sociocultural benefits to local communities [10].

It is impossible for a technology system to be born without an existing knowledge system already being in place [14]. However, usually, the traditional knowledge system that develops in society is not systematically or analytically formulated. Rather, it develops through a process of extraction, where best practices are identified throughout the historical development of the system. Local knowledge and technology systems are closely related to the opportunities and challenges faced by the community concerned. A local community's system of knowledge and technology can thus be viewed as a response to the opportunities and challenges of the local environment. In this respect, the palung system is also related to local thinking; the technological equipment used is based on local potential; and the distribution of palung products is based on local social and cultural networks. Salt is a form of income for local communities.

Palung salt is an integral aspect of the Balinese sociocultural system. According to the Balinese people, salt is an essential requirement of daily dishes. As well as this, when the Balinese finish cooking their meals, they give offerings in the form of rice and salt. These offerings, given as a token of gratitude to the spirits who have protected them, must be given before they eat their meal. The Balinese believe that salt must be used to resist evil forces.

Palung salt technology cannot be separated from the economic system of the local community. The discovery of local knowledge and technology is usually related to the economic needs of the community. This is in accordance with the concept developed by Kaplan and Manner's concept. This concept is entitled technoeconomics and refers to the fact that technology is related to people's livelihoods. Technology does not only refer to the equipment used in productive activities but also to the knowledge and value systems that are behind these productive activities. As a system of traditional knowledge and technology, palung salt technology is inherently traditional. Thus, palung salt is part of the collective memory of Balinese communities-it is both a common property and a common heritage [15].

There are numerous elements of local wisdom ingrained in the palung technique. First, there is the dominant role of human labor in palung production. The various production processes are conducted manually by locals. These processes begin with land preparation and end with harvesting. The process of making palung salt is closely related to the environment of the local community. For example, in terms of making the salt (a process called petasikan), a certain type of soil must be cultivated and then compacted. This type of soil is found in hilly areas and contains salt from the sea. In another process, saltwater that is taken from the sea is 
processed into nyah (saltwater brine). This water must be taken directly from the sea by workers using a traditional container made of palm leaves (dipikul).

After the petasikan soil is prepared, the salt farmers make nyah with the tanah sari. This soil is taken from mountainous areas near the coast. This soil is typically spread out to dry. The soil is also doused with seawater a number of times to ensure it has a high salt content. A plot of land is cultivated to prepare the tanah sari. Thus, there is a level of creativity in ensuring that the sea is integrated with the land in accordance with the conditions of the surrounding natural environment.

Aspects of local wisdom can also be seen in the different types of equipment used in the process of making the palung salt. The use of raw materials from the surrounding environment has made this technology sustainable. This is evident in the tinjungan tool used-this is a device used for filtering saltwater brine (air garam tua). The tinjungan is made of bamboo and is traditionally woven and shaped into a cone. The tinjungan typically has a diameter of $275 \mathrm{~cm}$ with a height of about $75 \mathrm{~cm}$ (Fig. 1). The area around the tinjungan is reinforced with a board that is made from local wood, usually sengon wood. Meanwhile, the inside of the cone is filled with coconut fibers to filter the saltwater brine so that the soil containing the salt does not fall into the reservoir of saltwater.

The brombong is another tool that is locally produced. This tool is made from old palm trees and is roughly 2 $\mathrm{m}$ long with a niche in the middle that holds the saltwater brine. The brombong is positioned horizontally on the ground so that it can be placed under the tinjungan. Then, the saltwater brine is drained away. Another unique tool is the palung. This tool is made from old coconut trees. While the brombong is used to hold saltwater brine from the tinjungan, the palung is used to evaporate the saltwater brine to obtain the palung salt.
Thus, it is clear that there is a mutually dependent relationship between the knowledge systems of Balinese communities and palung technology. There is a synergistic relationship between traditional knowledge, technology systems, economic systems, and the natural environment. This relationship has ensured that palung salt technology is able to sustain itself, as it involves using equipment made from local materials. The use of these local materials does not damage the environment.

Traditional knowledge systems in the salt-making process Palung salt-making requires special processes and techniques that represent the significance of the traditional values of Balinese communities. This knowledge process is important because it can be implemented as a nationwide method of production and influences every policy towards national salt production. It also relates to the manufacturing process, which can be separated into two phases, namely, techne and phronesis [16]. These knowledge processes of salt-making are often in the form of shared knowledge, which is implicitly or tacitly owned by several groups of people. This knowledge is practical in salt production systems, as stated by Grenier [8], who emphasizes that local Balinese people have a strong desire to utilize natural resources. Numerous traditional villages in Bali are still based on agriculture and marine resources. In these villages, knowledge regarding the utilization of natural resources tends to be co-opted by older generations. However, knowledge transformation, which is shared by the entire community, is subject to obstacles and challenges in efforts to inherit said knowledge through oral traditions. This leads the knowledge of processes and techniques to differ, depending on the community.

Knowledge transformation within salt-making requires a fundamental change from the subsistence production model to industrial orientation. By combining

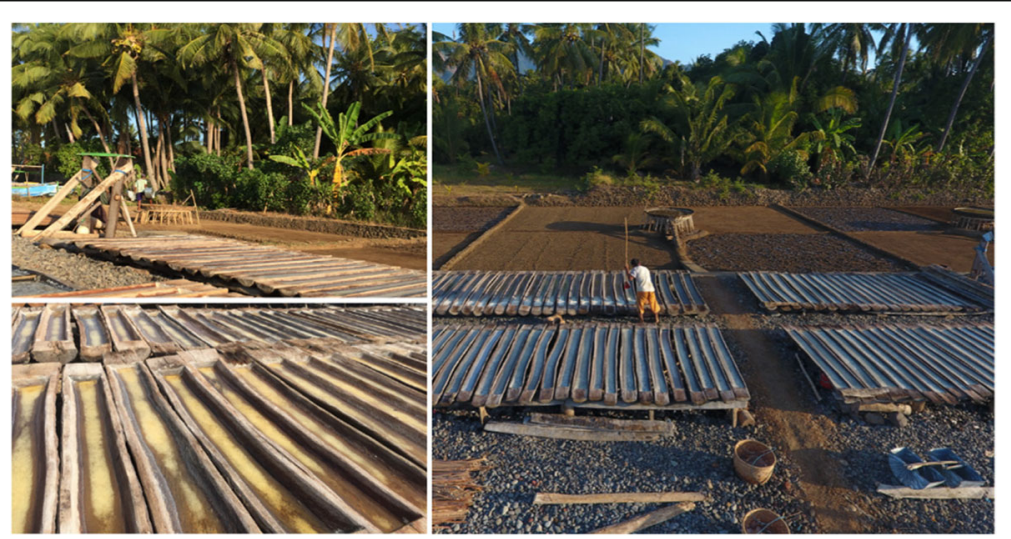

Fig. 1 Palung as the evaporation media to crystalize salt. The media uses old coconut trees and many traditional values are incorporated in the system 
the traditional knowledge of salt farmers with modern technology (e.g., greenhouses), the salt industry will continue to develop. As such, this section looks at the limitations of traditional technology in the process of krosok salt-making using the palung method; this method uses a low level of technological processing [5].

The majority of salt-making systems in Bali use the solar evaporation method. In the production process, there are some important steps that must be followed to maintain the salt's quality and distinctiveness. Palung salt has a slightly bitter taste compared to other salt types. There are roughly seven processes that must be carried out by salt farmers in order to produce salt. The processes are complex and involve soil extraction and saltwater brine processing (tulud). Ponds are usually owned by individuals, but some are owned by the state. A salt farmer (penyekap) typically works on their own land (pajak) with their family.

The first step in the process is preparing the pond, which is cleared of rubbish and dirt. The pond is leveled with the help of a rake that is made of bamboo (pangkrak). The land area that is used to process the tanah sari is $20.5 \mathrm{~m}$. After the soil is leveled, the palung is prepared on a drying table. Farmers will determine whether the palung is in a good or bad condition. If it is not of high quality, it will be worked on with the help of a palung expert. Currently, it is difficult to find palung experts due to a lack of interest among younger generations in pursuing this skill. Salt farmers need approximately 50 palung that will last for up to 30 years. After ensuring that all the equipment is suitable to use, the salt farmers can begin the production process.

Typically, salt farmers will begin each salt season by worshipping spirits in front of their houses and making offerings. Prayers are made and offerings are given by one female family member in the mornings and evenings. They pray for success in their salt-making and wish for a prosperous life. For Balinese people, the existence of salt is significant, as almost every stage of the Balinese life cycle is celebrated by offering up traditional food that is mixed with salt [17]. Thus, salt plays an important role in Balinese life, thus meaning that it is viewed as a sacred thing. Salt is a natural resource from the sea and a natural resource from the mountains-this is known as the nyegara-gunung concept. This concept is related to the existence of holy places of worship in the "center" and in the sea [18].

During the soil-management stage, the tanah sari is managed. This soil originates in hills and mountains. In some salt-producing centers that use palung technology, salt ponds are usually located near hilly areas or in mountains. This clearly highlights the beliefs of the Balinese people in relation to the aforementioned nyegaragunung concept. The pond area, which can be found quite close to the shoreline, is used to facilitate the transportation of seawater to the drying table. Meanwhile, green areas are located near the pond consists of nutrients and minerals. These green areas are overgrown with coconut trees and various plants that are believed by local residents to improve the soil layer and supply groundwater. Maintaining the green areas around the ponds is paramount to the quality of the salt and is referred to as "green conservation."

After the completion of the soil-management stage, the next step is to filter the seawater using the soil. To remove the saltwater brine, the leveled soil is doused with seawater. This also makes it difficult for grass and wild plants to grow in the ponds. This process is referred to as ngewayahi. It is usually conducted twice a day for four consecutive days. The soil is drained away after being rinsed with the seawater. It is then flattened using a tulud and is left for roughly four days. Then, the soil is mixed so that the salt content rises.

In one pajak, there are four plots of salt. The first plot must be smooth and loose. This smoothening is done using the pangkrak. Salt farmers believe that the drier the soil, the higher the mineral content. The dry soil must be collected in a way that ensures the air can circulate. The soil is then raised into a mound and placed in a tinjungan. The tanah sari is left for around 4 days and is watered twice a day [19].

In the process of transporting seawater, the salt farmers used a sene, which is made of thick plastic. The process of seawater collection also requires expert knowledge. The farmers usually wait for small waves to reach the shore. They then fill the sene with water and carry them on their shoulders. For generations, farmers have believed that small waves contain the highest levels of salt. Thus, they often wait for the right time (i.e., when small waves hit the shore). The sene is used to transport the seawater; which currently, it is made of plastic or aluminum, but in the past, it was apparently made from ntal leaves from the ntal tree, a type of palm tree that is becoming more scarce.

Ntal leaves are also used as filters in the tinjungan. To manufacture the saltwater brine using the tinjungan, a curtain-coating technique is used. The coating technique will be different in each petasikan (traditional village of salt farmers). In Les in Buleleng, for example, this coating technique is conducted using three layers: the ntal leaves form the base layer; sand, the tanah sari. In Tejakula, the farmers place five layers inside the tinjungan, and the layers consist of wood, tapis, sand, more tapis, and the soil extract. The soil extract in the uppermost layer is stepped on until it becomes solid, and then it is watered using seawater from the sene. The salt farmers can then obtain clean saltwater, which is stored in a container called a brombong. 
The next step involves placing the saltwater brine on a drying table using the palung. The saltwater brine is then evaporated to obtain the salt granules. If temperatures are sufficiently high, the salt should crystallize quite quickly. August is typically the most suitable month to harvest salt, as the hot weather means that the volume of the harvest will double.

The salt is then ready to be harvested when it is carded using bamboo. It is drained into containers (saingan) and must be placed at the top of the palung. The saltwater will then drip into the palung. Figure 2 illustrates the entire process of salt-making using the palung method.

Due to climate change, salt farmers in Bali now realize that they are vulnerable to the weather [20]. During the dry season (when salt is made), the weather can be unpredictable. In Tejakula and Amed, this is a cause of worry among salt farmers. However, farmers in Kusamba and Klungkung cover the palung so that it is safe from rain. The weather affects the success of the production process. If the water fails to evaporate, the production process must be repeated.

Family ties are important in the salt-making process, as the working relationship is based on family. There is no exploitative relationship in the salt business, as the labor is divided among groups. In this context, men and women enjoy the same level of involvement in the process. Balinese societies tend to be patriarchal [21]. However, salt farmers have strengthened the issue of gender equality by allowing men and women to do the same work.

\section{The sustainability of palung salt: opportunities and challenges}

Local wisdom and production processes make the economic activity of salt production unique and distinct to Bali. However, the palung salt industry does not meet basic needs. It has the potential to be developed to increase the economic standing of Balinese people, especially the palung salt farmers.

Opportunities are widespread in this regard. Data from Statistics Indonesia of Bali Province (2018) show that the price of traditional salt in Bali in 2018 was Rp 4750 per kilogram. The lowest price was between January and July, at Rp 4000 per kilogram, while the highest was between September and December, at Rp 6000 per kilogram. In areas of salt production along the north coast of central Java, salt prices were around Rp 550 per kilogram during the harvest and increased to $\mathrm{Rp} 1150$ per kilogram during the rainy season. Thus, it is clear that the cost of traditional Balinese salt, which includes palung salt, is relatively higher than the price of salt from other areas.

In an attempt to increase the economic value of palung salt, efforts have been made to produce artisan salt. This type of salt can only be found in Buleleng. Artisan salt is produced in Tejakula and is made of palung salt that is cleaned and mixed with mountain water, then

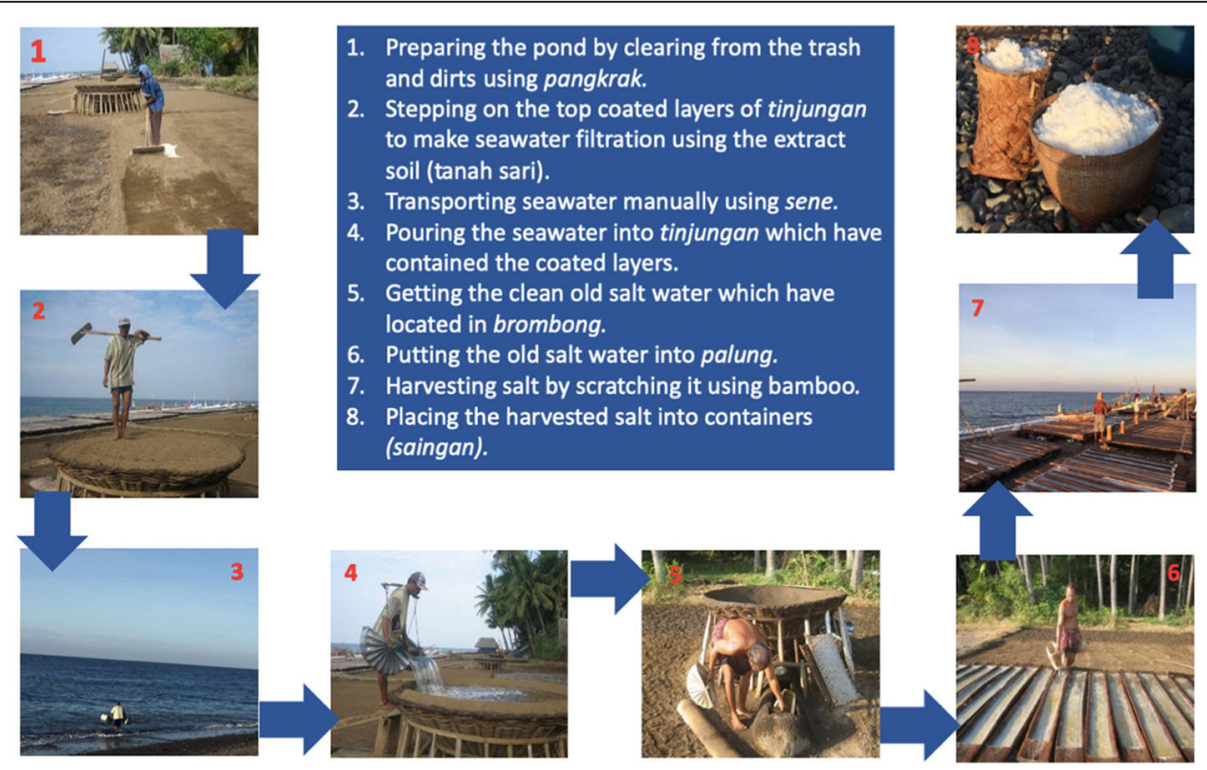

Fig. 2 Salt-making process using palung technology, which has 8 steps: (1.) Preparing the pond by cleaning from the trash and dirt using pangkrak; (2.) Stepping on the top-coated layers of tinjungan to make seawater filtration using the extract soil (tanah sari). (3.) Transporting seawater manually using sene; (4.) Pouring the seawater into tinjungan, which contain the coating layers; (5.) Getting the clean salt water, which has been located in brombong; (6.) Putting the salt water into palung; (7.) Harvesting salt by scratching it using bamboo; (8.) Placing the harvested salt into containers (saingan) 
evaporated in a greenhouse. This production process produces different types of salt. Artisan salt from Tejakula is used in cooking and in the beauty industry. Gourmet salt is also produced using the same process as artisan salt, but the raw materials differ in this regard. Gourmet salt produces porous pyramidal salt. Both artisan salt and gourmet salt are produced for the global market. However, they are also sold in the domestic market. In order to expand and strengthen the sale of gourmet salt in the domestic market, producers, with the help of the Indonesian government, cooperate with the Indonesian Hotel and Restaurant Association. In this way, gourmet salt is distributed to hotels and restaurants throughout Indonesia [22].

Tejakula artisan salt is sold to a wider market due to the establishment of a business network and product standardization. The business network was established through mutual cooperation between salt cooperatives and salt manufacturers. The cooperatives buy salt from the members and sells it to the manufacturing companies. As a result, the salt produced by the farmers, as cooperative members, can be absorbed, while the manufacturers can provide the raw materials. Product standardization is ensured through laboratory tests, product packaging, and labeling. Through these strategies, palung salt can penetrate the global market and reach countries such as Japan, South Korea, and France [5].

The development of the tourism industry, which is expanding to areas where palung salt is produced, creates a new opportunity for the improved economic welfare of palung salt farmers. Bali is the most preferred destination in Indonesia for tourists. Statistics Indonesia of Bali Province (2018) reported that in 2017, the number of foreign tourists who visited Bali reached 5,697, 739. The tourists came from all over the world. Tourism has led to employment opportunities for Balinese people in travel agencies, hotels, restaurants, etc. In this context, the production process and traditional technology used in palung salt can be turned into a tourist attraction. Foreign tourists are usually very interested in attractions that document the culture, lifestyle, and traditional activities of locals. Balinese palung salt will be attractive to tourists, as traditional salt production that uses palung can only be found in Bali. The potential of palung salt tourism is quite promising, as tourism along the north coast of Bali is dominated by natural attractions, especially marine tourism.

Tourism in Bali is similar to a double-edged sword. It does lead to opportunities for locals to improve their quality of life through increased earning opportunities. However, it also allows locals to earn money easily, meaning that they become quite fond of "fast cash." It is unsurprising that young people in Bali prefer to work in tourism, as the easy money they earn from tourism makes the work that their parents do (e.g., farming) quite undesirable. Consequently, young people in Bali do not have the necessary skills to cultivate the land. As an example of this, some local rice varieties are now rare or extinct [23].

The impact of tourism is being felt on palung salt communities. Some villages that were known for their salt production have stopped producing it, as the salt farmers have changed jobs. The areas in which salt is produced are becoming smaller on a daily basis, as they are being sold for tourism development. This land conversion has occurred in Tejakula (Buleleng), Kusamba (Klungkung), and Amed (Karangasem) [19]. This reflects the declining interest in producing palung salt. From this perspective, it can be said that the development of tourism is endangering the palung salt industry.

This declining interest in maintaining the salt industry is also reflected in government policies, which do not favor salt farmers. However, the government also imports salt. There is no synchronization of data between the relevant ministries; thus, the demand for salt versus the levels of traditional salt production are unclear. This lack of synchronization is always used as an excuse to import salt. Uncontrollable levels of imported salt lead to falling prices for traditional salt. This adversely affects salt farmers [24].

Another challenge to the sustainability of the palung salt industry is related to environmental changes in coastal areas. Beaches in Bali are prone to abrasion. Data collected by the Environment Agency of Bali Province showed that of Bali's $430 \mathrm{~km}$ of coastline, $187 \mathrm{~km}$ is suffering from abrasion, and $81.7 \mathrm{~km}$ of it is badly eroded. Beaches in southern Bali are some of the worst in this regard and include Pengambengan beach in Jembrana, Candidasa beach in the Karangasem district, and Padanggalam beach in Denpasar $[25,26]$. Sea dikes in Tejakula have been built to protect the beaches, and the palung salt farmers also benefit from these, as it allows them to keep producing salt.

\section{Conclusion}

The palung salt industry reflects the traditional knowledge system of Balinese coastal communities. This system guarantees the sustainability of locals and coastal ecosystems. Palung salt production has successfully penetrated the global market. However, the salt-making process is based on a knowledge system and traditional technology that faces threats in relation to coastal erosion, tourism, generational change, and government policies that are unhelpful to salt farmers.

\section{Acknowledgements}

The authors gratefully acknowledge the research funding from The Ministry of Research, Technology, and Higher Education, Republic of Indonesia, through the national strategic grant scheme Penelitian Terapan (101-178/ UN7.P4.3/PP/2019). 


\section{Authors' contributions}

YR formulated the research argumentation that is clearly stated in the "Introduction" section and verified the theoretical and analytical method. She encouraged all authors to investigate specific traditional values in the making of salt and supervised the findings of this work. She also coordinated the job descriptions among authors. STS performed the research findings of local wisdom aspects inside of the technology that used for the salt-making by palung system. He addressed and identified the traditional types of equipment and materials that contribute to the salt-making then analyzed why it valued by the salt farmers. MPU formulated the future analysis of salt production using palung technology. He classified and identified into two categories including challenges and opportunities of the future of palung technology system. NNM analyzed the local knowledge in the process of the salt-making from the very beginning until the end. It performed in the third section and supported with the figure explain the whole process of saltmaking. She also participated in the drafting of the final manuscript. SR performed the land use data and contributed the image visualization of the salt-making activity captured by a camera drone. MG and ME performed the data collection and processing. All authors read and approved the final manuscript.

\section{Funding}

The research was funded by The Ministry of Research, Technology, and Higher Education, Republic of Indonesia, through the national strategic grant scheme Penelitian Terapan (101-178/UN7.P4.3/PP/2019)

\section{Availability of data and materials}

Data sharing not applicable to this article as no datasets were generated or analyzed during the current study.

\section{Ethics approval and consent to participate}

Not applicable

\section{Competing interests}

The authors declare that they have no competing interest.

\section{Author details}

'Doctoral Program of History, Faculty of Humanities, Diponegoro University, Semarang 50275, Indonesia. ${ }^{2}$ Department of History, Faculty of Humanities, Diponegoro University, Semarang 50275, Indonesia. ${ }^{3}$ Department of Architecture, Faculty of Engineering, Diponegoro University, Semarang 50275, Indonesia. ${ }^{4}$ Marine Science Department, Faculty of Marine Science, Universitas Trunojoyo Madura, Bangkalan 69162, Indonesia. ${ }^{5}$ Chemical Engineering Department, Faculty of Engineering, Universitas Indonesia, Kampus UI, Depok 16424, Indonesia.

Received: 14 December 2018 Accepted: 12 September 2019 Published online: 16 October 2019

\section{References}

1. Rochwulaningsih Y. Salt production business potential in aceh as capital for the coastal communities welfare. J Marit Stud Natl Integr. 2018;2:23-30. https://doi.org/10.14710/JMSNI.V211.2882.

2. Arwiyah A, Zainuri M, Efendy M. Studi Kandungan $\mathrm{NaCl}$ di dalam Air Baku dan Garam yang Dihasilkan serta Produktivitas Lahan Garam Menggunakan Meja Garam yang Berbeda. J Kelaut Indones J Mar Sci Technol. 2015;8:1-9. https://doi.org/10.21107/jk.v8i1.804.

3. Susanto H, Rokhati N, Santosa GW. Development of traditional salt production process for improving product quantity and quality in Jepara District, Central Java, Indonesia. Procedia Environ Sci. 2015;23:175-8. https:// doi.org/10.1016/J.PROENV.2015.01.027

4. Bramawanto R, Sagala SL, Suhelmi IR, Prihatno H. Struktur dan Komposisi Tambak Teknologi Ulir Filter untuk Peningkatan Produksi Garam Rakyat. J Segara. 2015;11:1-11.

5. Rochwulaningsih Y, Gozan M, Effendy M, Masruroh NN, Wardoyo WW. Palung salt in Bali: strategies for the local product to penetrate global markets. Int J Trade Glob Mark. 2019;12:146. https://doi.org/10.1504/IJTGM. 2019.100351.

6. Rochwulaningsih Y. Tata Niaga Garam Rakyat Dalam Kajian Struktural. Citra Lekha. 2013;7:59-66.
7. Thornton TF, Scheer AM. Collaborative engagement of local and traditional knowledge and science in marine environments: A review. Ecol Soc. 2012; 17. https://doi.org/10.5751/ES-04714-170308.

8. Grenier L. Working with indigenous knowledge: a guide for researchersLouise Grenier, International Development Research Centre (Canada)Google Books. Ottawa: International Development Research Centre; 1998.

9. Kaplan D, Manners RA. Culture theory. Illinois: Waveland Press; 2000.

10. Pimbert M. Food sovereignty and autonomous local systems on JSTOR. RCC Perspect. 2015.

11. Nugroho K, Carden F, Antlov H. Generating and managing revenue. Manag World Herit Sites. 2009:95-6. https:/doi.org/10.1016/b978-0-7506-6546-9.50016-2.

12. Sevilla JC. Pengantar Metode Pennelitian. Jakarta: UI Press; 1993.

13. Bogdan RC, Biklen SK. Qualitative research for education: an introduction to theory and methods. Boston: Allyn and Bacon Inc; 1982.

14. Oluwatoyin K. Situating local knowledge within development agenda: some reflections, vol. 2; 2018. p. 1-23.

15. Rodriguez J, Fortier T. Cultural memory: resistance, faith, and identity. Austin: University of Texas Press; 2007.

16. Recuber T. Local knowledge matters. Rethink poverty what makes a good soc; 2017. p. 4-28.

17. Britain G. Rice, Ideology and the legitimation of hierarchy. R Anthropol Inst Gt Britain Irel Stable. 2011:26:445-67.

18. Mudana IG, Sutama IK, Widhari CIS. Local community entrepreneurship in Mount Agung Trekking. J Phys Conf Ser. 2018;953:012107. https://doi.org/10. 1088/1742-6596/953/1/012107.

19. Rochwulalningsih Y, Utama MP, Sulistiyono ST. Teknologi Garam Palung sebagai Warisan Sejarah Masyarakat Pesisir Bali. J Sej Citra Lekha. 2019;4:74-86.

20. Wahyono A. Kerentanan penambak garam akibat perubahan musim hujan di Desa Randutatah, Kabupaten Probolinggo. J Masy Dan Budaya. 2012;14: 519-40. https://doi.org/10.14203/JMB.V14I3.104.

21. Jha N. Gender and decision making in Balinese agriculture. Am Ethnol. 2004 31:552-72. https://doi.org/10.1525/ae.2004.31.4.552.

22. Garam Gourmet Bali Utara Diminati Pasar Mancanegara n.d. https:// maritim.go.id/garam-gourmet-bali-utara-diminati-pasar-mancanegara/ (accessed July 15, 2019).

23. Kurnianingsih A. Simulacra Bali: Ambiguitas Tradisionalisasi Orang Bali. Yogyakarta: Insist Press; 2008.

24. Yonvitner Y. Nasib Petambak Garam [In Bahasa]. Republika, 9 Juli 2019.

25. $187 \mathrm{Km}$ Garis Pantai Bali Terindikasi Abrasi [In Bahasa]. Antara News, 4 Jun 2017. https://bali.antaranews.com/berita/107025/187-km-garis-pantai-baliterindikasi-abrasi

26. Abrasi di Bali Kian Parah, Setahun Daratan Tergerus 5 Meter, Wilayah Ini Paling Mengkhawatirkan [In Bahasa]. Tribun Bali, 4 Agustus 2018. https://bali. tribunnews.com/2018/08/04/abrasi-di-bali-kian-parah-setahun-daratantergerus-5-meter-wilayah-ini-paling-mengkhawatirkan

\section{Publisher's Note}

Springer Nature remains neutral with regard to jurisdictional claims in published maps and institutional affiliations.

\section{Ready to submit your research? Choose BMC and benefit from:}

- fast, convenient online submission

- thorough peer review by experienced researchers in your field

- rapid publication on acceptance

- support for research data, including large and complex data types

- gold Open Access which fosters wider collaboration and increased citations

- maximum visibility for your research: over $100 \mathrm{M}$ website views per year

At $\mathrm{BMC}$, research is always in progress.

Learn more biomedcentral.com/submissions 